\title{
EFFECT OF Garcinia cambogia EXTRACT ON SERUM LEPTIN, GHRELIN, ADIPONECTIN AND INSULIN LEVELS AND BODY WEIGHTS IN RATS FED WITH HIGH LIPID DIET
}

\author{
Aysen Altiner ${ }^{1}$, Isil Sahin $^{1}$, Tanay Bilal ${ }^{2 *}$, Handan Aydin Vural $^{3}$ \\ ${ }^{1}$ Department of Biochemistry, ${ }^{2}$ Department of Animal Nutrition and Nutritional Diseases, ${ }^{3}$ Department of Pharmacology and Toxicology, \\ Faculty of Veterinary Medicine, Istanbul University, 34320 Avcilar, Istanbul, Turkey \\ ${ }^{*}$ Corresponding author, E-mail: tanbilal@istanbul.edu.tr
}

\begin{abstract}
Garcinia cambogia (malabar tamarind, bitter kola) is seen abundantly in the evergreen forests of Konkan in South India. Hydroxycitric acid, mainly obtained from Garcinia cambogia, was identified by the end of the 1960's as a strong competitive inhibitor of the extramitochondrial enzyme adenosine triphosphate citrate lyase. The objective of this study was to present the effect of Garcinia cambogia extract known as weakener on the supportive or preventive hormones (leptin, ghrelin, adiponectin, insulin) of obesity in the rats fed the diet containing hydrogenated-vegetable oil and cholesterol. For this purpose, thirty female 5-6 months-old Sprague-Dawley rats were randomly assigned to three groups. Each group consisted of 10 rats. Group 1 (as control group) was fed with a basal diet while the diets of Groups 2 and 3 contained the hydrogenated-vegetable oil (20\%) and cholesterol (1\%) beside of other nutrients. Garcinia cambogia extract containing 6\% hydroxycitric acid was added to the diet w/w of Group 3 after Day 30 up until Day 60. Blood samples were taken from animals on Days 0,30 and 60 of the trial period. Body weights were weighed in the blood sampling days before sampling. Serum leptin, ghrelin, adiponectin, insulin levels and body weights were not significantly different between groups in the each sampling day. Serum leptin levels were significantly higher on Day 60 than on Days 0 and 30 in Groups 2 and 3. Serum ghrelin levels in Group 3 significantly decreased on Day 30 and significantly increased on Day 60. Serum adiponectin levels in Group 1 were significantly lower on Day 0 than on other days. The levels in Group 3 were significantly higher on Day 60 than on Day 0. The serum insulin levels and body weights were not significantly different between the days in each group. In conclusion, the high lipid diet in doses used in the study (20\% hydrogenated-vegetable oil and $1 \%$ cholesterol) did not create fat accumulation or obesity in Sprague Dawley rats. Addition of Garcinia cambogia to diet (6\%, w/w) of rats fed with the high lipid diet indicated no effect on weight gain. The evidences obtained from this research do not support the role of Garcinia cambogia plant spreadly used as a weight loss facilitator.
\end{abstract}

Key words: adiponectin; Garcinia cambogia; ghrelin; insulin; leptin

\section{Introduction}

Obesity is an inevitable consequence of chronic positive energy balance (1). Although genetic factors most certainly play an important role in having a tendency towards obesity, the real culprit is the environment leading to a sedentary lifestyle and excessive food consumption. Hypertension is a health problem included in or contributing

Received: 3 November 2016

Accepted for publication: 20 July 2017 to serious diseases such as type-2 diabetes, coronary artery disease and paralysis and is on the rise worldwide (2). Weight loss can usually be achieved with dieting, behavioral modification, and exercise as well as with pharmacotherapy or surgery. Unfortunately, body weight is usually rapidly regained after the termination of such interventions (3). Therefore, pharmacological and dietary treatments that might counteract overeating are of increasing interest (4).

Garcinia cambogia (malabar tamarind, bitter kola) is seen abundantly in the evergreen forests 
of Konkan in South India. Many traditional recipes in Kerala use it for its different flavor (5). Historically, Garcinia cambogia has been used by the Yoruba tribe in West Africa in the treatment of the respiratory tract infections such as throat ache and coughing. Preliminary studies carried out on Garcinia cambogia seeds have demonstrated their antifungal, anticancer, antihistamine, antiulcerogenic, antimicrobial and antiviral effects (6). Various Garcinia types are still being used in traditional medicine for the treatment of hepatitis, laryngitis and oral infections (7). Liquid extracts of the Garcinia huillensis tree bark are used against sexual diseases, wounds, bronchitis, pneumonia, angina, measles and dermatitis in traditional Zaire medicine (8).

Farombi et al. (9) reported that Garcinia kola, a powerful and natural antioxidant, may be used in the chemotherapeutic prevention of cancer and other diseases. Hydroxycitric acid, mainly obtained from Garcinia cambogia and Garcinia indica extracts, was identified by Watson and Lowenstein (10) towards the end of the 1960's as a strong competitive inhibitor of the extramitochondrial enzyme adenosine triphosphate citrate lyase. It is an enzyme catalyzing the division of citrate into acetyl-CoA and oxaloacetate, which is an important step in the adenosine triphosphate citrate lyase lipogenesis (11). Hydroxycitric acid that is the main acid in fruit and rind suppresses de novo fatty acid synthesis by inhibiting this enzyme, and increases the rates of hepatic glycogen synthesis (12). Hydroxycitric acid also decreases the hyperglycemic and hyperinsulinaemic responses to oral or intragastric glucose loads (13).

Leonhardt et al. (14) reported that substances that block the fatty acid synthesis might be useful to prevent the body weight gain because weight gain in adults, and in particular weight regain after the body weight loss, usually comprises a buildup of fat. Researchers emphasized that hydroxycitric acid may be most effective in decreasing the food intake and preventing the body weight gain when the energy intake exceeds energy expenditure and the fatty acid synthesis is increased.

Adipose tissue plays an active role in regulation of the energy balance and nutrient metabolism (15). This tissue synthesizes and secretes a number of cytokine hormones that are involved in the regulation of energy homeostasis, insulin action, and lipid metabolism. Leptin and adiponectin are the adipose tissue-specific factors. The variation in these hormones may indicate the recovery in metabolic and cardiovascular risk profile after weight loss. Adiponectin, leptin and ghrelin are all involved in the regulation of energy homeostasis, the obesity and the moderate weight loss (1). Leptin has direct effect on some cell types including liver, bone and platelets, in vitro (16). While the amount of fat in body is responsible for $50-60 \%$ of plasma leptin, the factors such as age, gender, diurnal variation, hormones (primarily insulin) and cytokines (mainly TNF-a) are also effective on plasma leptin levels. Hyperleptinemia is known to be a component of metabolic syndrome (17).

Loss of fat mass causes increase of the circulating ghrelin levels, since ghrelin is a strong orexigenic signal (18). Plasma ghrelin levels in obese individuals have been found to be lower than those of thin individuals in the control group (19). Adiponectin in humans has been reported as a good marker of metabolic health (20). Adiponectin has sensitive to insulin, antiatherosclerotic and anti-inflammatory properties (21). Weight loss induced by especially lowcarbohydrate diet has been reported to increase the adiponectin concentrations in humans (22). Blood adiponectin concentrations in humans are negatively correlated with the abdominal fat mass and adipose tissue size (23).

Objective of this study was to determine the effect of Garcinia cambogia extract known as weakener on the supportive or preventive hormones (leptin, ghrelin, adiponectin, insulin) of obesity in rats fed the diet containing hydrogenated-vegetable oil and cholesterol.

\section{Materials and methods}

The study was approved by the Ethical Committee of Istanbul University (No:62/29042010), and was carried out according to the legal requirements of the relevant national authority. Thirty female 5-6 months-old Sprague-Dawley rats (pathogen-free) were used in the study. They were housed individually to standard cages $(33 \times 23 \times 12$ $\mathrm{cm})$ under the controlled conditions of temperature, lighting and humidity. Rats were randomly assigned to the three experimental groups of 10 animals each. The tap water and the appropriate diets of all groups (Table 1) were given as ad libitum from the beginning up until the end of trial period (Day 60). Garcinia cambogia fruit rind 
extract was provided by General Nutrition Products (General Nutrition Products, Inc., SC, USA). Group 1 (as control group) was fed with a basal diet while the diets of Groups 2 and 3 contained the hydrogenated-vegetable oil (20\%) and cholesterol $(1 \%)$ beside of other nutrients. Garcinia cambogia extract containing $6 \%$ hydroxycitric acid was added to diet $(w / w)$ of Group 3 after Day 30 up until Day 60. Body weights were weighed in the blood sampling days before sampling.

Blood samples were taken from all animals through coccygeal venipuncture on Days 0, 30 and 60 of the trial period after the fasting overnight and after the anesthetized with Ketamine-HCL (100 mg/kg i.p.). Serums were separated by centrifugation at $3000 \mathrm{rpm}$ for 20 minutes, and stored at $-86{ }^{\circ} \mathrm{C}$ until analysis. Serum leptin, ghrelin, adiponectin and insulin analyses were done by using commercially available kits with ELISA equipment ( $\mu$ Quant, Bio-Tek). Serum leptin levels were determined by RayBio Rat Leptin ELISA kit (ELR-Leptin-001, RayBiotech Inc., Norcross GA 30092, USA). Serum ghrelin levels were determined by Rat Ghrelin ELISA kit (E90991Ra, USCN Life Science Inc., Houston, TX 77082, USA).
Serum adiponectin levels were determined by AssayMax Rat Adiponectin ELISA kit (ERA25001, AssayPro, MO 63304, USA). Serum insulin levels were determined by Rat Insulin ELISA kit (CSB- E05070r, Cusabio Biotech, Wuhan, Hubei Province 430223, P.R.China).

Results were presented as mean \pm standard error. Data were compared at the significance level of $\mathrm{p} \leq 0.05$ by using the one way analysis of variance (Tukey's multiple range test) between the groups on each blood sampling day, and between the days within each group. All statistical analyses were performed by using the software package program (SPSS for windows, Standard version 10.0, 1999, SPSS Inc., Headquarters, Chicago, IL, USA).

\section{Results}

The comparisons between the groups and between the days were indicated in Figures. Serum leptin, ghrelin, adiponectin, insulin levels and body weights were not significantly different between groups in the each sampling day. Serum

Table 1: Composition of experimental diets

\begin{tabular}{|l|c|c|c|}
\hline Composition of nutrients (\%) & Group 1 & Group 2 & Group 3 \\
\hline Cracked barley & 23 & 10 & 4.5 \\
\hline Fish meal & 2 & 3 & 4 \\
\hline Cracked wheat & 42.5 & 30.5 & 40.5 \\
\hline Garcinia cambogia extract & - & - & 6 \\
\hline Hydrogenated vegetable oil & - & 20 & 20 \\
\hline Cholesterol & - & 1 & 1 \\
\hline Rasmol & 15 & 15 & 3.5 \\
\hline Liquid vegetable oil & 2 & 2 & 2 \\
\hline Soybean meal & 14.5 & 17.5 & 17.5 \\
\hline Vitamin-mineral mixture & 1 & 1 & 1 \\
\hline Calculation of nutrients & & & 19.5 \\
\hline Crude Protein (\%) & 19.5 & 19.5 & 13.7 \\
\hline Metabolisable energy (MJ/kg) & 12.5 & 13.7 & 14 \\
\hline
\end{tabular}

Vitamin-mineral mixture, kg: Vitamin A 12.000 U, Vitamin D $1.500 \mathrm{U}$, Vitamin E $104 \mathrm{U}$, Vitamin K 15 mg, Vitamin B, 14 mg, Vitamin $\mathrm{B}_{2} 11 \mathrm{mg}$, Vitamin $\mathrm{B}_{6} 14 \mathrm{mg}$, Vitamin $\mathrm{B}_{12} 20 \mathrm{mg}$, Folic acid $2.5 \mathrm{mg}$, nicotinic acid $78 \mathrm{mg}$, Pantothenic acid $26 \mathrm{mg}$, Biotin $334 \mathrm{\mu g}$, Choline chloride $1635 \mathrm{mg}$, Selenium $0.36 \mathrm{mg}$, Cobalt $0.46 \mathrm{mg}$, Iodine $1.41 \mathrm{mg}$, Zinc $95 \mathrm{mg}$, Manganese $68 \mathrm{mg}$, Copper $20 \mathrm{mg}$, Iron $104 \mathrm{mg}$

Group 1: Control group

Group 2: Group fed with the high lipid diet

Group 3: Group fed with the high lipid diet and Garcinia cambogia extract 

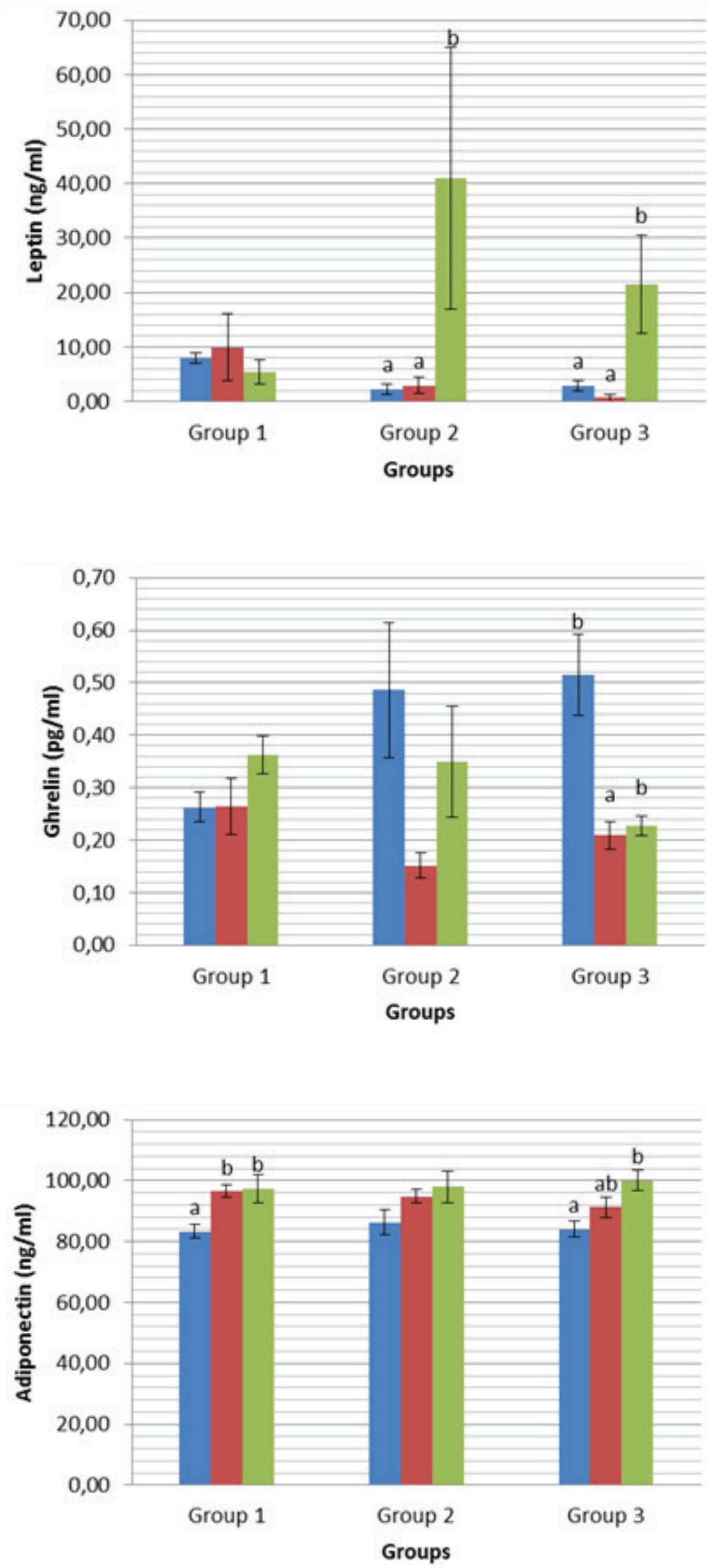

Figure 1: Serum leptin levels in rats fed with the high lipid diet

a,b: Different superscripts indicate significant differences between days $(\mathrm{p} \leq 0.05)$

Mean \pm standard error

Group 1: Control group

Group 2: Group fed with the high lipid diet

Group 3: Group fed with the high lipid diet and Garcinia cambogia extract

Figure 2: Serum ghrelin levels in rats fed with the high lipid diet

a,b: Different superscripts indicate significant differences between days $(\mathrm{p} \leq 0.05)$

Mean \pm standard error

Group 1: Control group

Group 2: Group fed with the high lipid diet

Group 3: Group fed with the high lipid diet and Garcinia cambogia extract

Figure 3: Serum adiponectin levels in rats fed with the high lipid diet

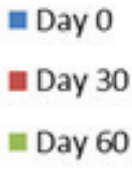

a,b: Different superscripts indicate significant differences between days $(\mathrm{p} \leq 0.05)$

Mean \pm standard error

Group 1: Control group

Group 2: Group fed with the high lipid diet

Group 3: Group fed with the high lipid diet and Garcinia cambogia extract 
Figure 4: Serum insulin levels in rats fed with the high lipid diet

Mean \pm standard error

Group 1: Control group

Group 2: Group fed with the high lipid diet

Group 3: Group fed with the high lipid diet and Garcinia cambogia extract

Figure 5: Body weights in rats fed with the high lipid diet

Mean \pm standard error

Group 1: Control group

Group 2: Group fed with the high lipid diet

Group 3: Group fed with the high lipid diet and Garcinia cambogia extract
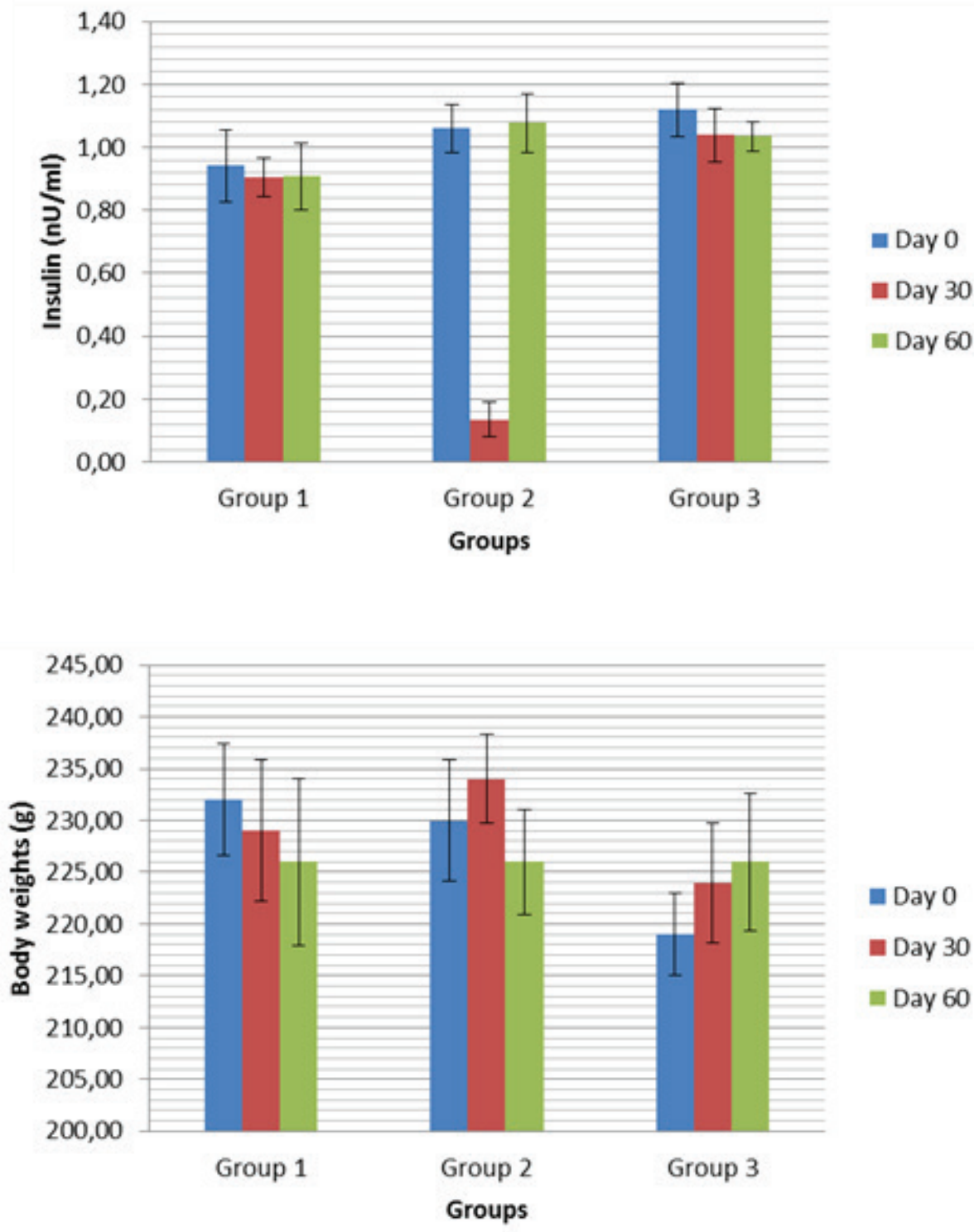

Table 2: The correlations between serum indices

\begin{tabular}{|c|c|c|c|c|}
\hline \multicolumn{2}{|c|}{ Indices } & Adiponectin & Leptin & Ghrelin \\
\hline & $\mathrm{r}$ & -0.083 & & \\
\hline Leptin & $\mathrm{p}$ & 0.518 & - & - \\
\hline & $\mathrm{n}$ & 63 & & \\
\hline & $\mathrm{r}$ & -0.101 & +0.022 & - \\
\hline Ghrelin & $\mathrm{p}$ & 0.118 & 0.868 & \\
\hline & $\mathrm{n}$ & 58 & -0.173 & -0.011 \\
\hline & $\mathrm{r}$ & +0.012 & 0.174 & 0.936 \\
\hline Insulin & $\mathrm{p}$ & 0.922 & 63 & 58 \\
\hline
\end{tabular}

r: Correlation coefficient

p: Significance level

n: Total sample number 
leptin levels were significantly higher on Day 60 than on Days 0 and 30 in Groups 2 and 3. Serum ghrelin levels in Group 3 significantly decreased on Day 30 and significantly increased on Day 60 . However, they were not significantly different between Days 0 and 60. Serum adiponectin levels in Group 1 were significantly lower on Day 0 than on other days. They increased with the advancing days in Group 3, and they were significantly higher on Day 60 than on Day 0. The serum insulin levels and body weights were not significantly different between the days in each group. The correlations between serum indices were indicated in Table 2 . No positive or negative significant correlations were determined between the total serum leptin, ghrelin, adiponectin and insulin levels.

\section{Discussion}

Preuss et al. (24) gave $4677 \mathrm{mg} /$ day hydroxycitric acid to subjects for 8 weeks, and determined that serum leptin levels gradually significantly decreased towards the end of 8 weeks. Gatta et al. (25) gave $2 \mathrm{~g}$ hydroxycitric acid with lunch to the male subjects and took the regular blood samples until the evening meal. They found the mean plasma leptin concentration to be $3.24 \mathrm{ng} / \mathrm{ml}$ in controls and $3.72 \mathrm{ng} / \mathrm{ml}$ in the hydroxycitric acid group. The researchers did not find a significant difference between two groups. Saito et al. (26) determined the leptin levels in Zucker obese rats, as $63.2 \mathrm{ng} / \mathrm{ml}$ in the control group and as $68.9 \mathrm{ng} / \mathrm{ml}$ in the experimental group that is given $154 \mathrm{mmol} / \mathrm{kg}$ hydroxycitric acid. The researchers reported that leptin did not mediate the unappetizing effect of hydroxycitric acid, and there was no significant difference regarding the serum leptin concentrations between the experimental groups.

Hayamizu et al. (27) reported that no statistically significant difference was found between experimental and control groups in the study where mice were given 3.3\% Garcinia cambogia with water containing $10 \%$ saccharose for 4 weeks. The researchers determined leptin levels as $11.7 \mathrm{ng} / \mathrm{ml}$ in the control group and $5.8 \mathrm{ng} / \mathrm{ml}$ in the experimental group. They reported that Garcinia cambogia administration decreased the serum leptin levels and the leptin/ white adipose tissue ratio without producing any changes in the appetite although leptin is a hormone with appetite controlling activity. In the present study, serum leptin levels were not significantly different between all groups. They were significantly higher on Day 60 than on Days 0 and 30 in Groups 2 and 3. This significant rising of serum leptin concentrations in Groups 2 and 3 on Day 60 were due to the fatty feeding because fatty feeding increases leptin synthesis (28). The fact that there is no significant difference between control and experimental groups is similar to the findings of Gatta et al. (25), Saito et al. (26) and Hayamizu et al. (27).

Faraj et al. (1) determined fairly low plasma ghrelin levels in subjects with morbid obesity. Cummings et al. (29) reported that plasma ghrelin levels increase after weight loss induced by diet. Gatta et al. (25) determined the mean plasma ghrelin level to be $1.11 \mathrm{ng} / \mathrm{ml}$ both in the control group and in the male subjects taking 2 $\mathrm{g}$ hydroxycitric acid with lunch. In the present research, no significant difference in serum ghrelin levels was found between groups. The feeding with the high lipid diet did not lead to significant changes in serum ghrelin levels in the study. At the same time, the addition of Garcinia cambogia to food did not cause any significant change in serum ghrelin levels and this is similar to the findings of Gatta et al. (25).

Gatta et al. (25) determined plasma insulin concentration as $18.3 \mu \mathrm{U} / \mathrm{ml}$ in the control group and as $18.64 \mu \mathrm{U} / \mathrm{ml}$ in the subjects taking $2 \mathrm{~g}$ hydroxycitric acid with lunch, and they could not find a significant difference between 2 groups. In the present study serum insulin concentrations were not significantly different between the groups in different days or between the days within each group. The finding that hydroxycitric acid has no effect on serum insulin levels was similar to the findings of Hayamizu et al. (30), Leonhardt et al. (31) and Gatta et al. (25).

Faraj et al. (1) reported that adiponectin is not a parameter associated with weight. Engström et al. (32) reported that adiponectin is indirectly proportional to insulin. In the study, serum adiponectin levels were not significantly different between 3 groups, and the levels significantly increased with the advancing days in Group 3. The levels were significantly higher on Day 30 than on Day 0 in the control group. It was not encountered any literature similar to the subject of this study as a result of the comprehensive literature searches.

Koshy et al. (5), added $1 \mathrm{mg} / 100 \mathrm{~g} /$ day 
of Garcinia cambogia flavonoids to the diets containing cholesterol, and did not observe significant changes in weight gain in the experimental animals compared to the control animals during 90 day duration of the study. Farombi et al. (9) added $200 \mathrm{mg} / \mathrm{kg}$ body weight/ day of kolaviron being a seed extract of Garcinia kola to the diet of rats for a week, and did not determine a significant change in the body weights compared to control group. The feeding with the high lipid diet or the high lipid diet and Garcinia cambogia extract did not cause the significant differences in the body weights of rats in the present study. Also, the significant changes did not occur in the body weights of rats in all groups with the advancing days. These findings are in consistent with the findings of Koshy et al. (5) and Farombi et al. (9).

In conclusion, the high lipid diet in doses used in the study $(20 \%$ hydrogenated-vegetable oil and $1 \%$ cholesterol) did not create fat accumulation or obesity in Sprague Dawley rats. Addition of Garcinia cambogia to diet $(6 \%, w / w)$ of rats fed with the high lipid diet indicated no effect on weight gain. The differences in the dose and effectiveness of Garcinia cambogia extract used in this study could be reason for the opposite findings obtained in the present study compared to the findings obtained in other some studies. For example, hydroxycitric acid that is an active ingredient of Garcinia cambogia can be found sometimes in the free acid form and sometimes in the lactone form, and it is thought to be the biologically active inhibitor of adenosine triphosphate citrate lyase of only free acid form (33). As a result, the evidences obtained from this research do not support the role of Garcinia cambogia plant spreadly used as a weight loss facilitator.

\section{Acknowledgment}

The study was financially supported by the Scientific Research Project Committee of Istanbul University. (Project number: T-7267).

Authors declare that there are no known conflicts of interest associated with this publication and that there has been no significant financial support for this work that could have influenced its outcome.

\section{References}

1. Faraj M, Hawel PJ, Phelis S, Blank D, Snirderman AD, Cianflone K. Plasma acylation-stimulating protein, adiponectin, leptin, and ghrelin before and after weight loss induced by gastric bypass surgery in morbidly obese subjects. J Clin Endocrinol Metab 2003; 88: 1594-602.

2. Hill JO, Peters JC. Environmental contributions to the obesity epidemic. Science 1998; 280: 1371-74.

3. Jebb SA. Obesity: from molecules to man. Proc Nutr Soc 1999; 58: 1-14.

4.Brandt K, Langhans W, Geary N, Leonhardt M. Beneficial and deleterious effects of hydroxycitrate in rats fed a high-fructose diet. Nutrition 2006; 22: 905-12.

5. Koshy AS, Anila L, Vijayalakshmi NR. Flavonoids from Garcinia cambogia lower lipid levels in hypercholesterolemic rats. Food Chem 2001; 72: $289-4$.

6. Oluyemi KA, Omotuyi IO, Jimoh OR, Adesanya OA, Saalu CL, Josiah SJ. Erythropoietic and anti-obesity effects of Garcinia cambogia (bitter kola) in Wistar rats. Biotechnol Appl Biochem 2007; 46: 69-72.

7. Iwu M, Igboko O. Flavonoids of Garcinia kola seeds. J Nat Prod 1982; 45: 650-1.

8. Bakana P, Claeys M, Totté J, et al. Structure and chemotherapeutical activity of a polyisoprenylated benzophenone from the stem bark of Garcinia huillensis. J Ethnopharmacol 1987; 21: $75-84$.

9. Farombi EO, Tahnteng JG, Agboola AO, Nwankwo JO, Emerole GO. Chemoprevention of 2 acetylaminofluorene-induced hepatotoxicity and lipid peroxidation in rats by kolaviron-Garcinia kola seed extract. Food Chem Toxicol 2000; 38: 535-41.

10. Watson JA, Lowenstein JM. Citrate and the conversion of carbohydrate into fat. Fatty acid synthesis by a combination of cytoplasm and mitochondria. J Biol Chem 1970; 245: 5993-6002.

11. Sullivan AC, Hamilton JG, Miller ON, Wheatley VR. Inhibition of lipogenesis in rat liver by hydroxycitrate. Arch Biochem Biophys 1972; 150: 183-90.

12.Nageswara Rao R, Sakeriak KK. Lipid-lowering and antiobesity effect of (-) hydroxycitric acid. Nutr Res 1988; 8: 209-12.

13.Wieling PY, Wachters-Hagedoorn RE, Bou- 
ter B, et al. Hydroxycitric acid delays intestinal glucose absorption in rats. Am J Physiol 2005; 288: 1144-9.

14. Leonhardt M, Hrupka B, Langhans W. Effect of hydroxycitrate on food intake and body weight again after a period of restrictive feeding in male rats. Physiol Behav 2001; 74: 191-6.

15. Ates A, Esen Gursel F, Bilal T, Altiner A. Effect of dietary Garcinia cambogia extract on serum lipid profile and enzymes in rats fed high-lipid diet. Iran J Vet Res 2012; 13: 1-7.

16. Sofer S, Eliraz A, Kaplan S, et al. Changes in daily leptin, ghrelin and adiponectin profiles following a diet with carbohydrates eaten at dinner in obese subjects. Nutr Metab Cardiovasc Dis 2013; 23: 744-50.

17. Comba B, Karakus K, Comba A. Hayvanc1likta grelin ve leptin hormonlarının kullanımı. [The usage of ghrelin and leptin hormones in livestock.] Igdır Univ J Inst Sci Tech 2015; 5: 99-105.

18. Weigle DS, Cummings DE, Newby PD, et al. Roles of leptin and ghrelin in loss of body weight caused by a low fat, high carbohydrate diet. J Clin Endocrinol Metab 2003; 88: 1577-86.

19. Tschöp M, Wawarta R, Riepl RL, et al. Post-prandial decrease of circulating human ghrelin levels. J Endocrinol Invest 2001; 24: 19-21.

20.Gao H, Fall T, van Dam RM. Evidence of a causal relationship between adiponectin levels and insulin sensitivity: a mendelian randomization study. Diabetes 2013; 62: 1338-44.

21.Angelidis G, Dafopoulos K, Messini CI, et al. The emerging roles of adiponectin in female reproductive system-associated disorders and pregnancy. Reprod Sci 2013; 20: 872-81.

22. Salehi-Abargouei A, Izadi V, Azadbakht L. The effect of low calorie diet on adinopectin concentration: a systematic review and metaanalysis. Horm Metab Res 2015; 47: 549-55.

23. Sauerwein H, Häußler S. Endogenous and exogenous factors influencing the concentrations on adiponectin in body fluids and tissues in the bovine. Domest Anim Endocrinol 2016; 56: S33-43.

24. Preuss HG, Bagchi D, Bagchi M, Rao CVS, Dey DK, Satyanarayana S. Effects of a natural extract of (-)-hydroxycitric acid (HCA-SX) and a com- bination of HCA-SX plus niasin-bound chromium and Gymnema sylvestre extract on weight loss. Diab Obes Metab 2004; 6: 171-80.

25. Gatta B, Zuberbuehler C, Arnold M, Aubert $\mathrm{R}$, Langhans W. Acute effects of pharmacological modifications of fatty acid metabolism on human satiety. Br J Nutr 2009; 101: 1867-77.

26. Saito M, Ueno M, Ogino S, Kubo K, Nagata $\mathrm{J}$, Takeuchi M. High dose of Garcinia cambogia is effective suppressing fat accumulation in developing male Zucker obese rats, but highly toxic to the testis. Food Chem Toxicol 2005; 43: 411-9.

27. Hayamizu K, Hirakawa H, Oikawa D, et al. Effect of Garcinia cambogia extract on serum leptin and insulin in mice. Fitoterapia 2003; 74: 267-73.

28. Machado MV, Coutinho J, Carepa F, Costa A, Proenca H, Cortez-Pinto H. How adiponectin, leptin, and ghrelin orchestrate together and correlate with the severity of nonalcoholic fatty liver disease. Eur J Gastroenterol Hepatol 2012; 24: 1166-72.

29. Cummings DE, Weigle DS, Frayo RS, et al. Plasma ghrelin levels after diet-induced weight loss or gastric bypass surgery. N Eng J Med 2002; 346: 1623-30.

30. Hayamizu K, Ishii Y, Kaneko I, et al. Effects of Garcinia cambogia (hydroxycitric acid) on visceral fat accumulation: a double-blind, randomized, placebo-controlled trial. Curr Therap Res 2003; 64: 551-67.

31. Leonhardt M, Münch S, Westerterp-Plantenga M, Langhans W. Effects of hydroxycitrate, conjugated linoleic acid, and guar gum on food intake, body weight regain, and metabolism after body weight loss in male rats. Nutr Res 2004; 24 : 659-69.

32. Engström BE, Burman P, Holdstock C, Karlsson FA. Effects of growth hormone (GH) on ghrelin, leptin, and adiponectin in GH-deficient patients. J Clin Endocrinol Metab 2003; 88: 5193208.

33. Jena BS, Jayaprakasha GK, Singh RP, Sakariah KK. Chemistry and biochemistry of (-) hydroxycitric acid from Garcinia. J Agric Food Chem 2002; 50: 10-22. 


\title{
VPLIV IZVLEČKA RASTLINE Garcinia cambogia NA RAVEN LEPTINA, GRELINA, ADIPONEKTINA IN INZULINA TER NA TELESNO TEŽO PRI PODGANAH, HRANJENIH S HRANO Z VISOKO VSEBNOSTJO MAŠČOB
}

\author{
A. Altiner, I. Sahin, T. Bilal, H. Aydin Vural
}

Povzetek: Garcinia cambogia je pogosta rastlina v tropskih gozdovih južne Indije. Hidroksicitronska kislina, ki je v velikih količinah v rastlini Garcinia cambogia, je bila v šestdesetih letih prejšnjega stoletja prepoznana kot močan kompetitivni zaviralec zunajmitohondrijskega encima ATP-citratna liaza. Namen raziskave je bil ugotoviti, ali izvleček rastline Garcinia cambogia lahko vpliva na izločanje hormonov, ki sodelujejo pri urejanjeu telesne teže (leptin, grelin, adiponektin, inzulin) pri podganah, hranjenih s hrano z visoko vsebnostjo maščob (rastlinska olja in holesterol). V raziskavo je bilo vključenih 30 podganjih samic seva SpragueDawley, starih 5 do 6 mesecev, ki so bile naključno razporejene v eno od treh poskusnih skupin. Podgane iz prve skupine so prejemale navadno hrano, podgane iz druge skupine pa hrano z dodanimi 20 \% rastlinskih olj ter $1 \%$ holesterola. Izvleček Garcinie cambogie je bil dodajan v hrano podganam iz tretje skupine, tako da so prejemale v hrani $6 \%$ hidroksicitronske kisline. Podgane so bile v poskusu 60 dni, s tem da so živali iz tretje skupine prejemale v hrani izvleček Garcinie cambogie od 30. do 60. dneva poskusa. Podganam smo odvzeli kri 1., 30. in 60. dan poskusa, ko so bile tudi stehtane. Raven letpina je bila v skupinah 2 in 3 statistično značilno višja na 60. dan v primerjavi s 1. in 30. dnevom. Raven grelina je bila v skipini 330 . dan poskusa statistično značilno nižja, 60. dan pa statistično značilno višja. Raven adiponektina je bila v skupini 1 statistično značilno višja 30 . in 60 . dan poskusa. Raven inzulina ter telesna teča pa se nista razlikovali med skupinamiv nobeni časovni točki. Ugotovimo lahko, da hranaz visoko vsebnostjo maščob ni povzročila v časovnem okviru raziskave debelosti, prav tako pa izvleček rastline Garicnia cambogia ni vplival na telesno tečo ali na raven hormonov in torej ni primeren kandidat za naravno zdravilo za pomoč pri hujšanju.

Ključne besede: adiponectin; Garcinia cambogia; ghrelin; insulin; leptin. 